\title{
PENERAPAN MODEL PEMBELAJARAN SENTRA DALAM \\ MATA KULIAH MICROTEACHING PADA MAHASISWA \\ JURUSAN PENDIDIKAN ISLAM ANAK USIA DINI (PIAUD) \\ FAKULTAS TARBIYAH DAN ILMU KEGURUAN (FTIK) IAIN PALU
}

\author{
Retoliah \\ Dosen Fakultas Tarbiyah dan Ilmu Keguruan Institut Agama Islam Negeri Palu
}

\begin{abstract}
ABSTRAK
Penelitian ini membahas tentang penerapan model pembelajaran sentra dalam mata kuliah microteaching pada mahasiswa jurusan PIAUD FTIK IAIN Palu. Penelitian ini menggunakan pendekatan kualitatif deskriptif, teknik pengumpulan data menggunakan observasi, wawancara dan dokumentasi. Teknik analis data menggunakan reduksi data, penyajian data dan verifikasi data. Hasil penelitian menunjukkan bahwa penerapan model pembelajaran sentra dalam mata kuliah microteaching yang dilaksanakan oleh mahasiswa semester VI/PIAUD FTIK IAIN Palu, memenuhi kriteria yang telah ditentukan. Mahasiswa PIAUD telah berhasil mendemonstrasikan model pembelajaran sentra, baik dilihat dari prosedur pembelajarannya, penggunaan media pembelajaran yang bervariasi maupun keterampilan dasar mengajar yang digunakan khusus untuk anak usia dini.
\end{abstract}

Kata Kunci : Kecerdasan interpersonal, Metode bermain peran

\section{PENDAHULUAN}

Kegiatan microteaching (pembelajaran mikro) pada Fakultas Tarbiyah dan Ilmu Keguruan (FTIK) IAIN Palu menempati posisi penting dalam kegiatan perkuliahan, terutama dalam membekali mahasiswa semester VI untuk memiliki segenap kompetensi keguruan melalui kegiatan simulasi mengajar. Simulasi mengajar adalah kegiatan pembelajaran yang dilakukan oleh mahasiswa dengan menggunakan situasi tiruan, secara berkelompok dalam ruang tertentu untuk mengembangkan bakat dan kemampuan serta keterampilan mahasiswa dalam mengelola proses pembelajaran sebelum terjun langsung ke dunia nyata di sekolah. Sebelum melaksanakan kegiatan simulasi mengajar, mahasiswa telah mendapat bekal teori melalui mata kuliah sebagai persyaratan microteaching.

Pembelajaran mikro merupakan salah satu bentuk model praktik kependidikan atau pelatihan mengajar bagi calon guru. Pembelajaran microteaching ini diarahkan untuk membentuk kemampuan keguruan mahasiswa baik bersifat umum dalam bentuk prinsip dan pendekatan yang berlaku untuk keperluan pembelajaran di sekolah/madrasah, maupun bersifat khusus yaitu teknik serta prosedur yang erat kaitannya dengan hakikat inti bahan ajar tertentu. Oleh karena itu pengalaman belajar pada microteaching ini mencakup kegiatan pemahaman teori dan latihan untuk pembentukan keterampilan 
keguruan ${ }^{1}$. Keterampilan keguruan atau keterampilan dasar mengajar yang dilatihkan dalam microteaching antara lain keterampilan membuka dan menutup pembelajaran, keterampilan menjelaskan, keterampilan bertanya, keterampilan variasi, keterampilan memberi penguatan. Semua jenis keterampilan tersebut berlangsung dalam proses interaksi antara praktikan guru dengan praktikan siswa dengan menggunakan model pembelajaran yang telah ditentukan.

Model pembelajaran merupakan suatu desain atau rancangan yang menggambarkan proses rincian dan penciptaan situasi lingkungan yang memungkinkan anak berinteraksi dalam pembelajaran, sehingga terjadi perubahan atau perkembangan pada diri anak. Dengan demikian hal yang mendasar bagi guru maupun calon guru dalam merancang pembelajaran adalah menentukan strategi atau langkah-langkah pembelajaran yang dapat menciptakan suasana pembelajaran yang kondusif dan pada akhirnya dapat mengembangkan potensi peserta didik secara komprehensif.

Khusus untuk peserta didik anak usia dini, potensi yang akan dikembangkan dalam proses pembelajaran meliputi 6 aspek perkembangan. Sebagaimana tercantum dalam Permendikbud RI, nomor 137 Tahun 2014 tentang Standar Nasional Pendidikan Anak Usia Dini, bahwa aspek-aspek perkembangan anak usia dini meliputi aspek agama dan moral, fisik motorik, kognitif, bahasa, sosial-emosional dan seni. Untuk mewujudkan hal tersebut, guru maupun calon guru perlu menggunakan model pembelajaran secara tepat yang dapat memberikan kebebasan kepada anak usia dini untuk mengembangkan bakat dan potensinya, sehingga seluruh aspek perkembangan anak usia dini dapat tercapai secara menyeluruh dan berkesinambungan. Model pembelajaran yang digunakan untuk peserta didik anak usia dini perlu dirancang sedemikian rupa karena masa usia dini memiliki dampak terhadap pengembangan kemampuan untuk berbuat dan belajar pada masa-masa berikutnya. Selain itu anak usia dini memiliki karakteristik tertentu yang khas dan tidak sama dengan orang dewasa, mereka selalu aktif, dinamis antusias dan ingin tahu terhadap apa yang dilihat, didengar dirasakan, mereka seolah-olah tak pernah berhenti bereksplorasi dan belajar.

Ada beberapa model pembelajaran inovatif yang dikembangkan pada usia dini antara lain model pembelajaran kelompok dengan kegiatan pengaman, model pembelajaran area, dan model pembelajaran sentra serta model pembelajaran berbasis sudut. Keempat model pembelajaran tersebut dipelajari dan dipraktikkan oleh mahasiswa semester VI Program Studi PIAUD FTIK IAIN Palu, pada mata kuliah microteaching. Yang paling dominan digunakan adalah model pembelajaran sentra yaitu model pembelajaran yang dalam proses pembelajarannya dilakukan dalam "lingkaran" (circle times) dan sentra bermain ${ }^{2}$. Model sentra mengelola kegiatan pembelajaran yang seimbang antara bimbingan guru dengan inisiatif anak. Proses pembelajaran sentra

\footnotetext{
${ }^{1}$ Arif, Arifuddin M, at.al. 2017. Modul Pembelajaran Micoteaching. Palu; FTIK IAIN Palu

2 PAUD Jateng. 2015. http://paudjateng.xahzgs.com/2015/05/10-model-pembelajaran-sentrapaud-pendidikan-anak-usia dini.html
} 
mengarah pada pengembangan aspek minat, potensi dan kekuatan anak, kegiatan bermain dalam proses pembelajaran sentra dilihat sebagai satu aktivitas kerja, oleh karena itu anak diberi kesempatan untuk memulai pengembangan ide sampai tuntas menyelesaikan hasil karyanya. Sentra pembelajaran PAUD terdiri dari sentra balok, sentra main peran kecil (mikro), sentra main peran besar (makro), sentra imtaq, sentra seni, sentra persiapan dan sentra bahan alam³.

"Sentra adalah zona atau area bermain anak yang dilengkapi dengan seperangkat alat main yang berfungsi sebagai pijakan lingkungan yang diperlukan untuk mendukung perkembangan anak dalam tiga jenis main, yaitu main sensorimotor atau main fungsional, main peran dan main pembangunan ${ }^{4}$. Main sensorimotor atau main fungsional merupakan main anak usia dini, dimana anak belajar melalui pancaindera dan hubungan fisik dengan lingkungan mereka. Permainan fungsional adalah aktivitas-aktivitas fisik seperti memantulkan bola, bermain kasar dan berguling ${ }^{5}$. Main peran adalah jenis kegiatan main yang dilakukan anak dengan cara bermain pura-pura dengan menirukan atau memperagakan sesuatu yang diinginkan. Bermain peran adalah kegiatan yang berfokus pada kegiatan dramatisasi, tempat anak-anak bermain untuk memerankan tugas-tugas anggota keluarga, tata cara dan kebiasaan dalam keluarga dengan berbagai perlengkapan rumah tangga serta kegiatan di lingkungan sekitar ${ }^{6}$. Main pembangunan adalah main untuk mempresentasikan ide anak melalui media. Media yang bersifat cair seperti air, pasir, lumpur, playdogh, tanah liat, tepung, krayon, pensil warna, pulpen. Media yang bersifat terstruktur yaitu media yang mempunyai bentuk dan mengarahkan anak agar dapat membentuknya menjadi sebuah karya, misalnya balok, lego, puzzle dan lego.

Model pembelajaran sentra merupakan model pembelajaran mutakhir yang dilaksanakan di lingkungan pendidikan anak usia dini dengan karakteristik utamanya memberikan pijakan (scaffolding) untuk membangun konsep aturan, ide, dan pengetahuan anak serta konsep densitas dan intensitas bermain. Hal ini dapat dibuktikan melalui hasil observasi bahwa pada umumnya TK/RA di Palu menggunakan model pembelajaran sentra. Oleh karena itu mahasiswa Prodi PIAUD lebih dominan dibimbing dan dilatih dalam menggunakan model pembelajaran sentra. Penggunaan model pembelajaran sentra pada saat microteaching, mengharuskan peserta didik dalam hal ini diperankan oleh teman praktikan berperilaku seperti anak usia dini mengikuti tuntutan skenario pembelajaran bernyanyi, berkegiatan, bermain, saling berebut alat permainan dsb. Kondisi peserta didik seperti ini memerlukan perhatian serta persiapan yang serius dari praktikan calon guru, agar dapat menyikapinya dengan sabar. Menurut Depdiknas,

\footnotetext{
${ }^{3}$ PAUD Jateng. 2015. http://paudjateng.xahzgs.com/2015/05/10-model-pembelajaran-sentrapaud-pendidikan-anak-usia dini.html

4 Asmawati, Luluk. 2014. Perencanaan Pembelajaran PAUD. Bandung : Rosdakarya

${ }^{5}$ Upton, Penney. 2012. Psikologi Perkembangan. Jakarta : Erlangga

${ }^{6}$ Nurani, Yuliani Sujiono. 2010. Bermain Kreatif Berbasis Kecerdasan Jamak. Jakarta : Indeks
} 
proses pembelajaran model sentra meliputi penataan lingkungan main, penyambutan anak, main pembukaan, transisi, kegiatan inti, kegiatan penutup dan evaluasi.

Berdasarkan uraian di atas, dapat dipahami bahwa focus kajian dalam tulisan ini adalah deskripsi tentang penerapan model pembelajaran sentra dalam mata kuliah microteaching mahasiswa jurusan PIAUD FTIK IAIN Palu. Deskripsi tentang model pembelajaran sentra yang berkaitan dengan prosedur pembelajaran sentra, macammacam pembelajaran sentra, media yang digunakan dalam pembelajaran sentra, serta deskripsi tentang microteaching mahasiswa jurusan PIAUD.

\section{METODE PENELITIAN}

Metode penelitian adalah cara berpikir dan berbuat yang dipersiapkan dengan sebaik-baiknya untuk mengadakan suatu penelitian guna mencapai tujuan penelitian. Metode yang digunakan dalam penelitian ini adalah metode deskriptif yakni penelitian yang bermaksud untuk memahami fenomena tentang apa yang dialami oleh subjek penelitian, misalnya perilaku, persepsi, motivasi, tindakan dan lain-lain, secara holistik dan dengan cara deskripsi dalam bentuk kata-kata dan bahasa pada suatu konteks khusus yang alamiah dan dengan memanfaatkan berbagai metode ilmiah ${ }^{7}$.

Pendekatan yang digunakan dalam penelitian ini adalah pendekatan kualitatif deskriptif, yakni prosedur penelitian yang dilakukan secara intensif, terperinci dan mendalam terhadap penampilan mahasiswa Prodi PIAUD FTIK IAIN Palu pada saat medemonstrasikan model pembelajaran sentra dalam kegiatan microteaching, yang menghasilkan data deskriptif berupa kata-kata tertulis atau lisan dari mereka sebagai pelaku yang diamati.

Pengumpulan datanya menggunakan teknik observasi, wawancara dan dokumentasi. Observasi dilakukan dengan cara pengamatan langsung terhadap kinerja mahasiswa semester VI/ PIAUD FTIK IAIN Palu dalam mendemonstrasikan atau mempraktikkan model pembelajaran sentra pada saat microteaching. Wawancara menggunakan pedoman wawancara semi terstruktur, peneliti menanyakan hal-hal yang berkenaan dengan model pembelajaran sentra, alasan mereka memilih model pembelajaran sentra tertentu untuk kegiatan microteaching, kesulitan mereka dalam menerapkan model pembelajaran tersebut dan persepsi mereka tentang pelaksanaan microteaching. Kemudian, dengan mendapatkan pokok-pokok jawaban tersebut, selanjutnya peneliti memperdalam pertanyaan tersebut lebih detail dengan masingmasing item-nya. Dalam penelitian ini, peneliti menggunakan triangulasi nara sumber untuk mendapatkan data yang valid. Dokumentasi merupakan pengambilan data yang diproses melalui dokumen-dokumen untuk memperkuat data yang diperoleh melalui

\footnotetext{
${ }^{7}$ Moleong, Lexy J. 2011. Metodologi Penelitian Kualitatif, edisi Revisi, cet. XXIX. Bandung : Remaja Rosdakarya
} 
wawancara dan observasi. Dokumentasi dalam penelitian ini digunakan oleh peneliti untuk mendapatkan data tentang kinerja mahasiswa semester VI Prodi PIAUD FTIK IAIN Palu dalam menerapkan model pembelajaran sentra pada saat microteaching, baik berupa data foto, tulisan atau dokumen-dokumen penting yang berhubungan dengan penerapan model pembelajaran sentra.

Teknik analisis data yang digunakan adalah reduksi data, penyajian data dan verifikasi data atau penarikan kesimpulan.

\section{HASIL DAN PEMBAHASAN}

\section{A. Penerapan Model Pembelajaran Sentra dalam Mata Kuliah Microteaching Mahasiswa Prodi PIAUD FTIK IAIN Palu}

Mahasiswa semester VI Prodi PIAUD FTIK IAIN Palu, yang melaksanakan praktik microteaching berjumlah 21 orang. Setiap mahasiswa bertugas menentukan sendiri model pembelajaran sentra yang akan digunakan, membuat persiapan dalam bentuk Rencana Kerja Harian (RKH), menyediakan media/alat yang akan digunakan dalam proses pembelajaran, serta menyiapkan instrumen penilaian.

Berdasarkan hasil pengamatan, setiap mahasiswa terlihat sangat antusias dan atraktif dalam memainkan peran sebagai seorang guru anak usia dini. Mereka berbicara, bersikap dan bertindak sesuai dengan kondisi anak usia dini. Model pembelajaran sentra yang didemonstrasikan oleh mahasiswa PIAUD adalah model sentra bermain peran dan model sentra alam serta model sentra agama. Untuk jelasnya dapat dilihat pada uraian berikut :

\section{Model Sentra Bermain Peran}

Kegiatan awal; Pada awal kegiatan guru (Srimisrawati) menyampaikan salam dengan suara yang lembut, menanyakan khabar siswa yang dijawab secara serempak 'baik ibu guru'. Selanjutnya guru mengajak siswa berdoa bersama dengan cara yang unik, lantunan doa yang sederhana diucapkan dengan berirama dibarengi dengan gerakan badan, setelah berdoa mereka bernyanyi juga disertai gerakan. Selanjutnya guru mengadakan appersepsi dalam bentuk pertanyaan 'siapa yang pernah menonton film Upin Ipin?' mereka semua mengangkat tangan pertanda bahwa mereka sangat menyukai film tersebut. Oke sekarang ibu guru pu nya cerita, tapi sebelumnya kita menyanyi dulu lagu dua mata saya. Setelah bernyanyi, guru memberikan acuan dengan cara menyampaikan kepada siswa bahwa setelah bercerita ibu akan menugaskan kalian untuk berperan sebagai tokoh dalam cerita, selain itu guru juga memberikan motivasi dengan cara menyampaikan bahwa pada akhir kegiatan ibu akan memberikan hadiah.

Kegiatan inti; Pada tahap ini guru menyampaikan topik cerita " Pak Gembala dan Pak Tani" Selanjutnya guru mulai bercerita sambil bertindak sebagai tokoh cerita secara bergantian kadang bertindak sebagai Pak tani, kadang bertindak sebagai gembala. Gaya guru bercerita sangat seru, gerakan maupun volume suara dan intonasinya menggambarkan tokoh yang diperankan. Siswa terpaku diam terlihat sangat antusias memperhatikan dan mendengarkan cerita, sampai akhirnya siswa terlonjak kaget saat 
guru berteriak "yap" dengan hentakan kaki sambil berkata srigala datang dan memakan semua domba-domba Pak gembala, sampai akhir cerita.

Kegiatan akhir; Pada tahap ini guru mengadakan evaluasi dengan cara: guru membagikan kertas yang ada gambar pak tani, pak gembala, serigala, domba, bunga, rumput, pohon dll. Guru menugaskan siswa berdiri dan memanggil siswa berdasarkan gambar karton yang ada di tangannya untuk berperan sesuai dengan gambar. Setelah itu guru memberikan nasehat berdasarkan makna yang terkandung dalam cerita, selanjutnya guru mengajak siswa bernyanyi dan pada akhir kegiatan guru mengajak siswa untuk berdoa sebelum pulang.

Berdasarkan hasil pengamatan tersebut dapat disimpulkan bahwa model sentra bermain peran yang didemonstrasikan oleh Srimisrawati telah terlaksana sesuai dengan kriteria atau ketentuan yang harus ada dalam pembelajaran sentra bahwa setiap sentra mendukung perkembangan anak dalam tiga jenis bermainnya yaitu bermain sensorimonitor atau fungsional, bermain peran dan bermain konstruktif (membangun pemikiran anak). Pada saat guru berperan sebagai pak tani, pak gembala, serigala, suara dan perilaku guru sesuai dengan yang diperankan. Saat itu siswa mengamati dengan seksama, menangkap rangsangan melalui penginderaan dan menghasilkan gerakan sebagai reaksinya. Hal ini terbukti pada saat anak-anak diminta untuk mendemonstrasikan kembali perilaku pak tani, gembala, mereka dapat mendemonstrasikannya dengan baik.

\section{Model Sentra Alam (diperankan oleh Nurhidayah)}

Kegiatan awal; Pada tahap ini guru melakukan kegiatan baris berbaris di depan kelas dan diiringi beberapa lagu seperti lonceng berbunyi, matahari bersinar terang. Selanjutnya guru mengajak siswa berdoa sebelum masuk kelas dan salam saat masuk kelas, dalam hal ini guru mengarahkan siswa agar masuk kelas dengan rapi dan teratur. Di kelas guru kembali mengajak siswa untuk bernyanyi bersama lagu selamat pagi, Tuhan saya Allah dan syair berdoa. Kegiatan ini dilakukan guru untuk menyenangkan perasaan siswa. Setelah itu guru mengajak siswa berdoa sebelum belajar dan membaca beberapa surah pendek : surah An-Nas, Al-Falaq, dan Al-Ikhlas).

Penggunaan model pembelajaran sentra alam mengharuskan guru menyiapkan media pembelajaran yang berasal dari alam sekitar, kegiatan pembelajarannya juga melalui pijakan awal artinya sebelum masuk di kelas ruang sentra, siswa terlebih dahulu duduk melingkar bersama di ruang khusus sebagai pijakan awal, siswa bernyanyi bersama lagu ikrar kita dan nama-nama buah, guru bercerita dan berdiskusi dengan siswa tentang hal-hal yang akan dilakukan pada kegiatan inti. Selanjutnya guru mengarahkan siswa untuk masuk ke dalam ruang sentra alam.

Kegiatan inti; Pada tahap ini guru menyiapkan sekitar empat kegiatan bermain siswa yaitu : 1) membuat bentuk buah-buahan dari plastisin yang terbuat dari bahan makanan agar aman digunakan dalam kegiatan bermain. Pada kegiatan ini guru mengarahkan dan membimbing anak tentang bagaimana cara membentuk plastisin menjadi bentuk buah-buahan, 2) membuat kolase buah-buahan dari beras yang sudah diberi bahan pewarna makanan. Dalam kegiatan ini guru mengarahkan anak agar mampu 
menempel beras yang berwarna tadi sesuai bentuk gambar pola buah-buahan yang sudah disediakan oleh guru, 3) menempel batang macis mengikuti pola bentuk huruf abjad. Dalam kegiatan ini guru sudah menyediakan kertas HVS yang bertuliskan salah satu huruf abjad, di antaranya huruf W,L,P,R dan T dan kemudian guru mengarahkan agar anak menempel batang macis pada tulisan huruf abjad tersebut, yaitu dengan cara pertama-tama batang macis diolesi lem kemudian ditempelkan pada pola tulisan, 4) menulis bentuk huruf abjad di atas pasir. Dalam kegiatan ini guru sudah menyiapkan pasir halus dalam sebuah wadah seperti baskom yang agak besar kemudian guru juga menyiapkan beberapa bentuk huruf abjad yang ditulis di kertas HVS di antaranya yaitu huruf W,L,AE,P dan R, kemudian guru mengarahkan anak untuk menuliskan huruf-huruf tersebut pada pasir yang ada di dalam baskom dan guru juga menanyakan tentang tekstur dari pasir.

Recalling; Dalam kegiatan ini guru mengarahkan anak untuk merapikan mainannya atau media yang sudah digunakan dalam kegiatan pembelajaran di kegiatan inti. Setelah selesai merapikan mainan anak diajak duduk melingkar bersama guru kemudian guru menanyakan perasaan anak setelah bermain, guru juga menanyakan tentang kegiatan bermain yang dilakukan pada sentra bahan alam. Guru juga bercerita tentang perbuatan yang tidak baik agar anak-anak dapat memahami perbuatan yang baik dan tidak baik, serta anak dirahkan untuk menunjukkan hasil karyanya yang telah dibuat di sentra bahan alam pada saat kegiatan inti.

Kegiatan istirahat; Dalam kegiatan ini guru mengarahkan anak-anak mencuci tangan dengan menggunakan sabun, mengeringkan tangan dengan serbet atau lap tangan, sebelum kegiatan makan bersama. Hal ini dilakukan agar anak terbiasa hidup bersih. Setelah anak-anak siap untuk makan, guru mengingatkan untuk membaca doa sebelum makan. Saat makan anak-anak dianjurkan untuk tidak bercerita, selesai makan mereka kembali membaca doa sebagai ungkapan rasa syukur kepada Allah swt atas segala nikmat yang diberikan kepada hamba-Nya. Setelah itu anak-anak diberi kebebasan untuk bermain di luar kelas.

Penutup; Pada kegiatan ini anak-anak diarahkan kembali untuk masuk kelas, membaca doa bersama sebelum pulang. Sebelum membaca doa, guru mengajak anakanak bernyanyi bersama dua lagu sebagai berikut: Lagu 1 "Kalau kau senang hati tepuk tangan (2x tepuk tangan) kalau kau senang hati dan memangnya begitu, kalau kau senang hati tepuk tangan (2x tepuk tangan)." Lagu 2 "Bila aku berdoa kuangkat tanganku, dengan suara rendah tidak berteriak, berdoa sungguh-sungguh agar dikabulkan segala permohonan hamba yang beriman, tangan ke atas, tangan ke samping, tangan ke depan, ditarik perlahan." Setelah itu guru melakukan tanya jawab tentang kegiatan yang dilakukan selama satu hari atau kegiatan awal sampai di kegiatan akhir. Selanjutnya guru mengarahkan anak untuk membaca doa pulang bersama dan jabat tangan dengan guru sebelum keluar kelas.

Berdasarkan hasil pengamatan dapat disimpulkan bahwa model sentra alam yang didemonstrasikan oleh Nurhidayah memenuhi seluruh kriteria yang dikehendaki dalam pembelajaran anak usia dini yakni bernyanyi disertai dengan gerakan badan, lagu yang 
dinyanyikan bermakna spiritual, bermain sensorimonitor dan berkegiatan dengan menggunakan berbagai bahan yang variatif yang bersumber dari alam sekitar. Proses pembelajaran dilakukan dalam lingkaran (circle times) yakni guru dengan anak duduk dalam posisi melingkar untuk memberikan pijakan sebelum dan sesudah bermain sebagai ciri khas dari pembelajaran sentra. Style guru dalam berinteraksi dengan anak sangat bagus, suaranya lembut penuh keibuan, ada nada membujuk, memotivasi anak-anak agar semangat belajar. Pembelajarannya tuntas mulai dari awal sampai akhir.

\section{Model Sentra Agama (diperankan oleh Putriani Koraag)}

Penerapan model sentra agama kurang lebih sama dengan sentra alam yakni kegiatan awal; guru mengarahkan anak-anak berbaris rapi, mengajak untuk bernyanyi bersama lagu lonceng berbunyi, setelah itu berdoa sebelum masuk di kelas. Setelah anakanak masuk di kelas, guru mengajak mereka duduk melingkar sebagai pijakan awal, guru mengajak anak-anak bernyanyi lagi: Tuhan saya Allah, lagu huruf hijaiyah ( alif ba ta), setelah itu guru mengajak anak-anak membaca surah an-Nas, al-Falaq, al-Ikhlas. Setelah itu dengan suara yang lembut guru menanyakan hal-hal yang sudah dipelajari, memberikan motivasi untuk senantiasa belajar, menyampaikan acuan pembelajaran dengan cara memberitahu anak-anak kegiatan apa saja yang akan dilakukan pada ruang sentra.

Kegiatan inti; Pada kegiatan ini siswa bermain, berkegiatan di bawah arahan guru siswa berusaha mencari pasangan huruf hijaiyah, mencocokkan potongan karton, menempel gambar mesjid di atas karton. (media yang digunakan terdiri dari potongan karton, gambar mesjid, huruf-huruf hijaiyah, gambar orang shalat, dsb). Selesai bermain siswa diarahkan untuk merapikan mainan.

Istirahat; Pada kegiatan ini siswa diarahkan mencuci tangan sebelum makan, berdoa, berbagi makanan, bermain bebas setelah makan bersama.

Penutup; Pada tahap ini siswa kembali duduk melingkar di ruang pijakan awal. Guru menanyakan perasaan siswa selama melakukan kegiatan, kemudian berdiskusi tentang perilaku yang kurang baik. Berdoa sebelum pulang dan guru memberi nasehat tentang hal-hal yang harus dilakukan sesampainya di rumah.

Berdasarkan hasil pengamatan dapat disimpulkan model pembelajaran sentra agama yang didemonstrasikan oleh Putriani Koraag sesuai dengan temanya ibadah sangat kental dengan nilai-nilai spiritual, lagu-lagunya mengajak anak-anak untuk mengenal Tuhan, mengenal huruf hijaiyah, menghafal ayat-ayat al-Qur'an surah al-Ikhlas, al-Falaq, an-Nas. Media pembelajarannya juga mendukung yakni gambar mesjid, gambar orang shalat, kegiatan dilaksanakan untuk menanamkan keimanan dan ketaqwaan terhadap Tuhan Yang Maha Esa, menanamkan nilai-nilai kehidupan beragama. Penampilan guru sangat sederhana, lembut bersahaja, sabar menghadapi pertanyaan-pertanyaan, sesuai dengan kriteria guru AUD. Prosedur pembelajarannya juga sesuai dengan proses pembelajaran sentra yang dilakukan dalam lingkaran sebagai dasar pijakan sebelum dan sesudah bermain. 


\section{Model Sentra Seni (diperankan oleh Nurfaidah)}

Kegiatan awal; Pada tahap ini guru mengajak anak-anak berbaris di depan kelas sebelum masuk ruangan sambil menyanyikan lagu lonceng berbunyi, setelah bernyanyi anak-anak membaca doa bersama sebelum masuk kelas. Saat di kelas guru dan anak-anak duduk melingkar (pijakan sebelum bermain), guru memberi salam pada anak-anak menanyakan khabarnya dan dilanjutkan dengan kegiatan berdoa sebelum belajar. Setelah berdoa guru mengajak anak-anak bernyanyi lagu "pada hari minggu". Selanjutnya guru bertanya "tau tidak kita bermain apa hari ini ? hari ini kita menempel dan mewarnai. Bahan-bahan yang akan kita gunakan saat bermain antara lain : bahan cangkang telur, kertas bergambar, pensil warna, beras yang sudah diwarnai dan lem. Pada saat memperkenalkan bahan tersebut guru juga menjelaskan cara penggunaannya.

Kegiatan inti; Pada tahap ini guru mengajak anak-anak masuk ke ruang/sentra bermain. Sebelum bermain guru menginstruksikan atau mencontohkan cara mengoleskan lem dan menempelkan cangkang telur dan beras yang sudah diwarnai. Selanjutnya anakanak bermain menempel dan mewarnai, sementara itu guru berkeliling mengamati kegiatan anak-anak dan sesekali menjawab pertanyaan dengan lembut. Setelah bermain guru mengumpulkan karya anak-anak dan mengajak mereka kembali ke tempat sebelumnya.

Istirahat; Pada tahap ini guru bertanya "siapa yang bawa bekal makanan ? yang punya makanan lebih silahkan berbagi dengan temannya. Guru juga mengingatkan untuk mencuci tangan sebelum makan dan mengajak mereka berdoa. Setelah makan bersama guru mengajak anak-anak kembali berdoa dan menyuruh mereka merapikan peralatan makan dan minumannya.

Kegiatan akhir; Guru menanyakan perasaan anak-anak pada saat bermain dan menanyakan kegiatan apa saja yang mereka lakukan. Selanjutnya guru mengevaluasi setiap lembar kerja dan menyampaikan hasilnya pada anak-anak. Sebelum pulang guru mengajak anak-anak bernyanyi dan berdoa bersama.

Berdasarkan hasil pengamatan dapat disimpulkan bahwa model sentra seni yang didemonstrasikan oleh Nurfaidah sesuai dengan prosedur pembelajaran sentra yakni pembelajaran dilakukan dalam lingkaran sebagai pijakan awal sebelum masuk pada sentra bermain dan sesudah bermain. Pada saat kegiatan berlangsung anak-anak difasilitasi untuk memperluas wawasan dan mengembangkan ide melalui kegiatan mewarnai gambar, menempel cangkang telur dan beras berwarna. Pembelajaran dilakukan secara tuntas mulai dari awal sampai akhir kegiatan.

\section{Model Sentra Memasak (diperankan oleh Hamzie Marie)}

Kegiatan awal; Ketika bel berbunyi, guru mengarahkan anak-anak berbaris di depan kelas, merapikan barisan sambil mengajak anak-anak bernyanyi, memberi salam kepada anak-anak, menanyakan khabar mereka. Setelah itu anak-anak diarahkan masuk ke kelas duduk dalam posisi melingkar sebagai pijakan awal. Setelah di kelas anak-anak diajak untuk berdoa sebelum belajar : baiklah sebelum kita belajar mari kita berdoa bersama (guru memilih salah satu anak untuk memimpin doa dan menyuruh anak yang lain mengikuti). Setelah itu guru menjelaskan kegiatan-kegiatan yang akan dilakukan di 
area bermain, sambil bertanya : "anak-anak siapa yang tau minuman apa yang rasanya manis dan berwarna putih"? anak-anak menjawab "susu", siapa yang suka makan roti ? saya ibu guru. Sekarang kita akan membuat makanan dan minuman yang sehat. Sebelumnya guru mengajak anak-anak bernyanyi "nama-nama rasa" siapa tahu apa rasa gula, manis...manis...manis...itu rasanya, siapa tahu apa rasa garam, asin...asin...asin itu rasanya, cobalah katakan apa rasa cabai, pedas...pedas...pedas aku tak suka, itu semua nama-nama rasa kita harus tahu janganlah lupa. Guru mengajak anak-anak bernyanyi dengan cara guru yang bertanya anak-anak yang menjawab. Selanjutnya guru mengajak anak-anak masuk ke ruang sentra bermain.

Kegiatan inti; Pada tahap ini guru menugaskan anak-anak berbaris sambil berkata "anak-anak perhatikan ibu ; yang karton warna merah rotinya dioles dengan susu coklat, yang karton warna kuning susunya diseduh, yang karton warna hijau tehnya juga diseduh". Selanjutnya guru menyuruh anak-anak memilih permainan yang disukai, guru mengarahkan anak-anak " susunya dioles perlahan yaa... supaya susunya tidak tumpah... tuangkan air dinginnya sedikit lebih dulu yaa... kemudian tuang air panasnya... supaya susunya tidak panas" Guru bolak balik memperhatikan siswanya melakukan kegiatan masing-masing.

Istirahat; Guru mengarahkan anak-anak merapikan peralatan kemudian mengajak mereka keluar dari ruang bermain dengan tertib. Selanjutnya guru mengajak anak-anak mencuci tangan sebelum makan, berdoa bersama sebelum dan sesudah makan.

Penutup; Pada tahap ini guru bersama anak-anak kembali duduk melingkar, guru menanyakan kepada anak-anak tentang kegiatan yang mereka lakukan, menanyakan tentang rasa susu, rasa teh, warna susu dan teh. Selanjutnya guru mengajak mereka bernyanyi lagu pelangi dan berdoa sebelum pulang.

Berdasarkan hasil pengamatan tersebut dapat dipahami, bahwa pembelajaran sentra memasak yang ditampilkan oleh Hamzie Marie sesuai dengan prosedur pembelajaran sentra yakni kegiatan awal maupun akhir dilakukan dalam lingkaran (circle times) yaitu guru bersama anak-anak duduk dalam posisi melingkar untuk memberikan pijakan sebelum dan sesudah bermain. Kegiatan pembelajarannya seimbang antara bimbingan guru dengan inisiatif anak, karena pada saat anak-anak bermain sesekali guru memberikan petunjuk tentang cara menakar air, susu dan sebagainya.

Dengan demikian dapat disimpulkan bahwa mahasiswa PIAUD telah berhasil mendemonstrasikan beberapa model pembelajaran sentra karena baik prosedur pembelajarannya, media pembelajarannya, karakteristik pembelajaran pada masingmasing sentra telah memenuhi kriteria yang diinginkan yakni bermain sensomonitor agar anak-anak dapat menangkap rangsangan melalui penginderaan dan menghasilkan gerakan sebagai reaksinya. Anak-anak bermain dengan benda untuk membantu menghadirkan konsep yang telah dimilikinya. 


\section{B. Kendala dalam Penerapan Model-Model Pembelajaran Sentra pada Mata Kuliah Microteaching Mahasiswa Prodi PIAUD FTIK IAIN PALU}

Penerapan model pembelajaran sentra dalam mata kuliah microteaching mahasiswa Prodi PIAUD FTIK IAIN Palu, mengalami beberapa kendala antara lain sebagai berikut.

\section{Kendala dalam Mempersiapkan Bahan-Bahan/Media Pembelajaran}

Pada tahap persiapan, mahasiswa diberi kewenangan sepenuhnya untuk mempersiapkan segala sesuatu yang berkaitan dengan hal-hal yang akan digunakan pada saat demonstrasi, misalnya : Rencana Kerja Harian (RKH) dan bahan-bahan/media. Mereka mimilih sendiri model pembelajaran serta topik yang akan didemonstrasikan. Ada beberapa kendala yang mereka hadapi terutama pada saat praktik uji coba bahan yang akan digunakan untuk demonstrasi. Sebagaimana disampaikan oleh Ayu Lestari : "Pada saat menyiapkan bahan, saya menonton youtube untuk mencontoh cara mencampur cat air dengan sabun, ternyata setelah dipraktikkan tidak muncul warna, saya bingung sendiri. Akhirnya saya mengikuti saran teman untuk menggunakan pewarna makanan."

Kendala yang dihadapi oleh mahasiswa tersebut adalah pada uji coba mencampur bahan dari cat air dengan sabun agar muncul warna tertentu seperti yang dicontohkan dalam youtube namun dalam praktiknya tidak berhasil, akhirnya mahasiswa tersebut mecari solusi dari permasalahan yang dihadapi dengan cara meminta bantuan temannya. Hal ini menunjukkan bahwa mahasiswa yang bersangkutan memiliki motivasi yang tinggi untuk berkreasi, sehingga ada perbedaan dengan teman yang lain, sekaligus ingin menemukan sesuatu yang baru.

Adapun kendala yang dialami oleh Putriani Koraag dalam hal mempersiapkan bahan/media pembelajaran yang akan digunakan dalam model pembelajaran sentra ibadah, adalah "Saya bingung menentukan alat peraga apa yang akan digunakan untuk model pembelajaran sentra ibadah, karena belum jelas apakah ada perbedaan media yang digunakan antara model sentra dan model area. Menghadapi kondisi tersebut saya berinisiatif untuk menggunakan media sederhana sesuai dengan pemahaman saya."

Mahasiswa tersebut bingung menentukan alat peraga untuk sentra ibadah karena yang bersangkutan menganggap ada perbedaan dalam penggunaan alat peraga antara dua model tersebut. Pada dasarnya alat peraga yang digunakan sama yakni maket tempat ibadah, perlengkapan ibadah berupa sajadah, mukena, peci, kain sarung, gambar-gambar tata cara berwudhu, buku iqra, kartu huruf hijaiyah, tasbih, juz amma, al-qur'an, dan sebagainya yang meliputi alat-alat permainan lima aspek rukun Islam dari syahadah sampai dengan haji. Dengan demikian upaya yang ditempuh oleh mahasiswa tersebut dalam mengatasi kesulitan dalam menentukan media adalah hal yang tepat karena media yang digunakan dalam model sentra maupun area sama.

Kendala lain yang dihadapi oleh mahasiswa adalah yang berkaitan dengan kemampuan merancang/mendesain media pembelajaran yang dipilih serta persoalan dana, sebagaimana disampaikan oleh Nurfaidah: "Saya kesulitan dalam hal pembuatan media pembelajaran yang berkaitan dengan model sentra seni mewarnai dan menempel, 
kemampuan saya terbatas dalam merancang media dan dana juga harus siap untuk biaya bahan. Oleh karena itu saya hanya menggunakan media yang sederhana."

Kendala yang dihadapi oleh mahasiswa tersebut dalam merancang media dan terbatasnya dana dalam menyiapkan bahan yang dibutuhkan dalam menerapkan model pembelajaran sentra seni, menyebabkan media pembelajaran yang digunakan oleh mahasiswa tersebut pada saat praktik sangat sederhana terdiri dari bahan cangkang telur, kertas bergambar, pensil warna, beras yang sudah diwarnai dan lem. Bahan-bahannya sederhana karena yang bersangkutan sesuai pernyataannya memiliki keterbatasan dalam merangcang media yang lebih bagus dan dananya terbatas.

\section{Kendala yang Dihadapi Mahasiswa pada saat Simulasi}

Pada saat simulasi, mahasiswa mengalami beberapa kendala yang berkaitan dengan respon siswa yang dalam hal ini diperankan oleh teman sendiri. Sebagaimana diungkapkan oleh mereka, antara lain: Hamzie Marie mengungkapkan bahwa "Apa yang saya rencanakan dalam RKH model pembelajaran sentra memasak sebagian tidak sesuai dengan praktik, karena kondisi siswanya teman sendiri yang berpura-pura menjadi anakanak terkadang memunculkan pertanyaan yang tidak terduga, akhirnya kewalahan sendiri. Namun hal tersebut tidak berlarut-larut, karena saya berusaha dengan tenang memberikan jawaban sesuai dengan kemampuan saya."

Perencanaan yang dibuat oleh Hamzie Marie sebagaimana tertuang dalam RKH sudah tersusun dengan rapi, namun pada saat demonstrasi cara membuat minuman dari susu campur teh, susu putih, dan cara mengoles roti dengan coklat, mengalami kesulitan ketika temannya yang berperan sebagai siswa mengajukan pertanyaan-pertanyaan yang membuat Hamzie terlihat kewalahan. Kalau menghadapi anak usia dini yang sebenarnya tentu akan berbeda kondisinya tidak akan muncul pertanyaan yang menjebak. Upaya yang ditempuh oleh mahasiswa tersebut dalam menghadapi pertanyaan temannya sudah tepat karena yang bersangkutan meskipun kewalahan, tetap bersikap tenang dan memberikan jawaban sesuai kemampuannya.

Demikian pula pernyataan dari Nurhidayah, bahwa guru harus mampu merespon pertanyaan siswa yang sifatnya dadakan, hal ini merupakan salah satu tantangan yang dihadapi pada saat microteaching karena siswanya teman sendiri.

Kondisi yang dialami oleh semua praktikan pada umumnya sama karena yang dihadapi adalah teman yang berpura-pura sebagai siswa, terkadang muncul pertanyaan yang tak terduga yang mengharuskan praktikan guru kreatif dalam menjawab pertanyaan.

Selain itu Annisa menyampaikan bahwa "ada perbedaan antara RKH dengan praktik, karena harus mengikuti kondisi anak-anak, mereka berebutan alat permainan padahal sudah dibagi kelompok. Seharusnya anak-anak secara berkelompok berlomba membawa balok sesuai warna ke tempat tertentu, tapi kelompok lain menerobos dan merampas alat permainan temannya. Untuk mengatasi hal itu saya membujuk anak-anak agar mengikuti arah permainan".

Kendala yang dialami oleh mahasiswa tersebut menghadapi perilaku temantemannya yang bertindak sebagai siswa membuat yang bersangkutan kewalahan untuk menyesuaikan antara apa yang telah disiapkan dalam RKH terutama dalam mengatur 
mereka membawa balok dengan tertib sesuai warna ke tempat yang telah disediakan. Namun demikian mahasiswa tersebut berusaha membujuk anak-anak agar mengikuti aturan permainan.

Putriani Koraag menambahkan bahwa "kesulitan lain yang dihadapi adalah pada kegiatan menarik perhatian/minat anak, susah memunculkan minat anak secara spontan karena yang dihadapi adalah teman sendiri yang sudah bisa membaca apa yang diinginkan gurunya."

Kendala yang dihadapi oleh Putriani Koraag dalam hal menarik perhatian siswa agar muncul motivasi dalam diri mereka untuk belajar tidak dapat menjadi alat ukur karena siswanya adalah teman sendiri yang sudah mengetahui apa yang akan dilakukan guru. Kegiatan belajar yang dilakukan oleh siswa semata-mata hanya mengikuti permainan simulasi, jadi tidak sepenuhnya karena cara guru menarik perhatian siswa.

Adapun kendala yang dihadapi oleh Ayu Lestari sebagai berikut: "Saya mengalami kesulitan pada bagian motorik, susah mengatur gerakan siswa, disuruh melakukan sesuatu ternyata lain yang dilakukan, maunya sendiri bergerak, hal ini terjadi karena siswa yang dihadapi adalah teman sendiri."

Kendala Ayu Lestari sebagai guru dalam mengatur gerakan siswa memang terlihat jelas pada saat praktik. Ada beberapa siswa yang membuat gerakan menyimpang dari petunjuk guru karena siswa tersebut terlihat dengan sengaja melakukan gerakan lain untuk memancing respon guru. Sikap Ayu Lestari dalam menghadapi perilaku siswa tersebut tetap tenang dan berusaha memberikan penjelasan dan mendemonstrasikan gerakan yang sebenarnya.

Berdasarkan uraian tersebut dapat dipahami bahwa para praktikan guru mengalami beberapa kendala pada saat microteaching tentang penerapan model pembelajaran sentra. Kendala tersebut bervariasi, ada yang mengalami kendala pada aspek bahan atau media yang digunakan, kendala pada aspek RKH yang tidak sesuai dengan praktik, kendala dalam menjawab pertanyaan-pertanyaan dadakan, kendala dalam mengatur gerakan (aspek motorik) siswa. Kendala tersebut muncul karena yang bertindak sebagai siswa adalah teman sendiri yang kadang dengan sengaja berbuat sesuatu agar dapat mengetahui respon guru dalam menyikapi aktivitas mereka. Hal ini diketahui pada saat diberikan kesempatan kepada mereka untuk mengomentari penampilan praktikan. Meskipun demikian kondisinya, kegiatan microteaching tetap terlaksana sesuai prosedur, karena masing-masing praktikan berusaha sendiri mencari solusi dari kendala yang dihadapi.

Selain hal tersebut di atas, penulis juga mempertanyakan tentang kesan mahasiswa terhadap pelaksanaan microteaching. Pada umumnya menjawab sangat setuju karena dengan adanya simulasi pada mata kuliah microteaching dan diberikannya kewenangan untuk menentukan sendiri model pembelajaran sentra yang diminati serta dengan adanya ketentuan harus berbeda sentra antara satu sama lain, menyebabkan mereka dapat berkreasi sesuai dengan kemampuan masing-masing. Sebagaimana pernyataan mereka, antara lain :

1) Putriani Koraag "Saya senang dengan pembelajaran mikro, karena di samping menambah ilmu pengetahuan, juga membantu untuk mengingat kembali materi yang 
terlupakan. Alat permainan yang dibuat teman-teman sangat beragam sehingga menambah wawasan kami tentang berbagai jenis media serta cara membuat dan menggunakannya, sesuai dengan materi yang akan dipelajari."

Ungkapan mahasiswa tersebut menunjukkan bahwa penggunaan media yang beragam dan dirancang sendiri oleh masing-masing praktikan, berimplikasi pada bertambahnya wawasan mahasiswa dalam merancang dan menggunakan media tertentu sesuai tema yang dibahas. Selain itu mereka dapat melakukan refleksi terhadap materi yang telah dipelajari sebelumnya, mengingat kembali hal-hal yang sempat terlupakan.

2) Nurhidayah : "Saya senang dengan kegiatan praktik seperti ini karena dapat menambah ilmu, apa yang diperoleh dari mata kuliah lain bisa diaplikasikan pada saat kita microteaching seperti mata kuliah Desain pembelajaran AUD, Media Pembelajaran AUD, Strategi Pembelajaran AUD termasuk Psikologi belajar, dan lainlain semua dapat diaplikasikan. Selain itu ada perasaan puas pada saat melihat siswa senang, terkadang ada kejadian lucu yang muncul dari sikap pura-pura dari teman sendiri."

Kesan mahasiswa tersebut memang benar, karena pelaksanaan microteaching merupakan aplikasi dari ilmu keguruan antara lain kurikulum, desain pembelajaran, strategi/metode pembelajaran, psikologi belajar, media pembelajaran, dll. Selain itu proses pembelajaran mikro memiliki keunikan sendiri karena terkadang muncul sesuatu yang mengejutkan dari sikap pura-pura praktikan siswa.

3) Sri Misrawati : "Saya senang dengan pembelajaran mikro, karena melalui praktik kita menjadi terlatih dalam hal pengaturan suara yang harus lembut terhadap anak-anak, kita juga terlatih dalam hal menarik perhatian anak-anak. Hal ini semua menjadi bekal menghadapi anak usia dini yang sebenarnya.

Pernyataan mahasiswa tersebut sesuai dengan tujuan dari pembelajaran mikro antara lain melatih mahasiswa untuk menguasai bagian demi bagian setiap jenis ketrampilan mengajar antara lain ketrampilan variasi yang diarahkan pada kemampuan untuk mengatur nada ( tinggi rendahnya) suara, terutama bagi anak-anak usia dini yang memerlukan perlakuan khusus seperti suara yang lembut, mengajak, membujuk, dan sebagainya.

\section{KESIMPULAN}

1. Penerapan model-model pembelajaran sentra dalam mata kuliah microteaching yang dilaksanakan oleh mahasiswa semester VI/PIAUD sangat beragam, antara lain model sentra bermain peran, sentra alam, sentra agama, sentra seni, dan sentra memasak. Mahasiswa PIAUD telah berhasil mendemonstrasikan model pembelajaran sentra, baik dilihat dari prosedur pembelajarannya ( kegiatan awal, kegiatan inti dan kegiatan penutup), juga media pembelajaran yang bervariasi serta karakteristik dari masingmasing model pembelajaran sentra, telah memenuhi kriteria. Mereka berupaya keras membuat siswa bermain, berkegiatan, bernyanyi yang menjadi ciri khas pembelajaran anak usia dini, syair dalam lagu yang dinyanyikan mengajak anak-anak untuk mengenal Allah swt, menghafal surah-surah pendek, dan sebagainya. Yang 
membedakan hanyalah pada kreativitas gurunya dalam mengelola pembelajaran, style guru yang memiliki keunikan masing-masing, juga jenis/ragam media pembelajaran serta penggunaannya. Keterampilan dasar mengajar yang dilatihkan seperti menarik perhatian siswa dengan cara bernyanyi disertai gerakan, suasana yang diciptakan oleh mahasiswa sangat sesuai dengan kondisi anak-anak usia dini, karena mereka bertutur bersikap sangat lembut. Appersepsi juga dilakukan dengan cara mengingatkan siswa tentang apa yang telah mereka pelajari sebelumnya dan menghubungkan materi yang akan dipelajari hari itu. Pada kegiatan inti anak-anak diberi kebebasan untuk bermain, berkegiatan sesuai dengan minat masing-masing. Pada akhir kegiatan mahasiswa mereviu materi yang telah dipelajari dengan cara mengingatkan kegiatan apa saja yang telah dilakukan pada ruang atau area bermain, demikian pula evaluasi dilaksanakan dalam bentuk pengamatan dan hasilnya disampaikan pada akhir kegiatan sebelum bernyanyi dan berdoa sebelum pulang.

2. Kendala dalam penerapan model pembelajaran sentra pada mata kuliah microteaching mahasiswa jurusan PIAUD FTIK IAIN Palu, antara lain; dalam hal persiapan mereka kesulitan mendesain media/alat peraga yang akan digunakan karena ketidakmampuan dana serta kurang terampil dalam merancang sendiri media yang dibutuhkan, solusinya praktikan menggunakan media sederhana. Adapun kendala yang dihadapi pada saat simulasi, antara lain terjadi perbedaan antara RKH dengan simulasi misalnya dalam mengatur gerakan siswa yang dalam hal ini diperankan oleh teman sendiri terkadang mereka bergerak semaunya, tidak sesuai dengan petunjuk, solusinya praktikan dengan tenang membujuk dan mengarahkan siswa untuk bergerak sesuai yang diinginkan. Selain itu sering muncul pertanyaan tak terduga hanya untuk mengetahui respon praktikan guru. Walapun demikian kondisinya, pada umumnya mahasiwa merespon positif terhadap pelaksanaan microteaching khususnya dalam menerapkan model pembelajaran sentra yang bervariasi, karena selain menambah wawasan, mereka juga terlatih dalam bertutur dan bersikap dengan lembut sesuai dengan kondisi anak usia dini.

\section{IMPLIKASI PENELITIAN}

Temuan penelitian ini diharapkan bermanfaat bagi Fakultas Tarbiyah dan Ilmu Keguruan khususnya jurusan PIAUD terutama dalam hal pengembangan model pembelajaran sentra secara teoritis maupun praktis. Demikian pula bagi dosen pengampu mata kuliah khususnya microteaching temuan penelitian ini dapat dijadikan sebagai referensi dalam membimbing mahasiswa jurusan PIAUD 


\section{DAFTAR PUSTAKA}

Arif, Arifuddin M, at.al. 2017. Modul Pembelajaran Micoteaching. Palu; FTIK IAIN Palu.

Asmawati, Luluk. 2014. Perencanaan Pembelajaran PAUD. Bandung : Rosdakarya

Moleong, Lexy J. 2011. Metodologi Penelitian Kualitatif, edisi Revisi, cet. XXIX. Bandung : Remaja Rosdakarya

Nurani, Yuliani Sujiono. 2010. Bermain Kreatif Berbasis Kecerdasan Jamak. Jakarta : Indeks

PAUD Jateng. 2015. http://paudjateng.xahzgs.com/2015/05/10-model-pembelajaransentra-paud-pendidikan-anak-usia dini.html

Upton, Penney. 2012. Psikologi Perkembangan. Jakarta : Erlangga 